\title{
Hereditary intrinsic factor deficiency in China caused by a novel mutation in the intrinsic factor gene-a case report
}

\author{
Jing Ruan, Bing Han * ${ }^{*}$, Junling Zhuang, Miao Chen, Fangfei Chen, Yuzhou Huang and Wenzhe Zhou
}

\begin{abstract}
Background: Hereditary intrinsic factor deficiency is a rare disease characterized by cobalamin deficiency with the lack of gastric intrinsic factor because of gastric intrinsic factor (GIF) mutations. Patients usually present with cobalamin deficiency without gastroscopy abnormality and intrinsic factor antibodies.

Case presentation: A Chinese patient presented with recurrent severe anemia since age 2 with low cobalamin level and a mild elevation of indirect bilirubin. The hemoglobin level normalized each time after intramuscular vitamin B12 injection. Gene test verified a c.776delA frame shift mutation in exon 6 combined with c.585C > A nonsense early termination mutation in exon 5 of GIF which result in the dysfunction of gastric intrinsic factor protein. The hereditary intrinsic factor deficiency in literature was further reviewed and the ancestry of different mutation sites were discussed.

Conclusions: A novel compound heterozygous mutation of GIF in a Chinese patient of hereditary intrinsic factor deficiency was reported. It was the first identified mutation of GIF in East-Asia and may indicate a new ancestry.
\end{abstract}

Keywords: Megaloblastic anemia, Cobalamin deficiency, Intrinsic factor

\section{Background}

Vitamin B12 or cobalamin deficiency is characterized by megaloblastic anemia with neurological problems and can be caused by numerous acquired and inherited diseases [1]. Decreased intake, impaired gastric absorption including pernicious anemia and gastrectomy, impaired intestinal absorption caused by parasites infection are common acquired causes. As for inherited diseases, the mechanisms vary from impaired cobalamin absorption, defects of cobalamin transport to failure of cellular cobalamin metabolism. Two hereditary diseases have been found to cause cobalamin malabsorption including Imerslund-Grasbeck syndrome (IGS) and hereditary intrinsic factor deficiency (IFD) [2].

\footnotetext{
*Correspondence: rjgrass@126.com

Department of Hematology, Peking Union Medical College, Hospital, Chinese Academy of Medical Sciences, No.1 Shuaifuyuan, Dongcheng District, Beijing 100730, China
}

IFD is caused by homozygous or compound heterozygous mutation in the gene of gastric intrinsic factor on chromosome 11q12. It presents in early childhood with the lack of gastric intrinsic factor, while the gastric acid secretion is normal and no autoantibody to intrinsic factor is found. It is a rare disease mostly occurring in the Europe [3]. Here we present a Chinese family identified to have hereditary intrinsic factor deficiency with a new mutation site in GIF that has not been reported.

\section{Case presentation \\ Clinical manifestation}

The proband was a 16-year-old Chinese boy with a history of patent ductus arteriosus. The child was initially evaluated for severe anemia at the age of 2. Severe megaloblastic anemia, low cobalamin level and a mild elevation of indirect bilirubin were found. The hemoglobin level normalized after intramuscular vitamin B12 injection and oral folate with unknown dosage. He did not

(c) The Author(s). 2020 Open Access This article is licensed under a Creative Commons Attribution 4.0 International License, which permits use, sharing, adaptation, distribution and reproduction in any medium or format, as long as you give appropriate credit to the original author(s) and the source, provide a link to the Creative Commons licence, and indicate if changes were made. The images or other third party material in this article are included in the article's Creative Commons licence, unless indicated otherwise in a credit line to the material. If material is not included in the article's Creative Commons licence and your intended use is not permitted by statutory regulation or exceeds the permitted use, you will need to obtain permission directly from the copyright holder. To view a copy of this licence, visit http://creativecommons.org/licenses/by/4.0/. The Creative Commons Public Domain Dedication waiver (http://creativecommons.org/publicdomain/zero/1.0/) applies to the data made available in this article, unless otherwise stated in a credit line to the data. 
have severe symptoms the following years. At age 8 , he was admitted to the hospital for the recurrence of anemia induced by upper airway infection. He also had jaundice and tea-colored urine. The hemoglobin was $57 \mathrm{~g} / \mathrm{L}$, mean cell volume was $97.8 \mathrm{fL}$, and the cobalamin level was $80 \mathrm{pg} / \mathrm{mL}$. Hemolytic anemia was also found with the indirect bilirubin to be $43.0 \mathrm{umol} / \mathrm{L}$ and lactate dehydrogenase to be $1832 \mathrm{U} / \mathrm{L}$. Rous test, Coombs test, erythrocyte osmotic fragility test, glucose-6-phosphate dehydrogenase activity and the count of CD55/CD59 negative cells were normal. The ultrasound of the spleen showed a mild enlargement. Bone marrow indicated megaloblastic erythroid hyperplasia. He was treated with intramuscular injection of vitamin B12 at the dosage of $0.5 \mathrm{mg}$ every other day and his hemoglobin increased to $114 \mathrm{~g} / \mathrm{L}$. The patient had recurrent anemia 4 times from age 10 to 16 and the hemoglobin regained normal after B12 supplement. He came to our hospital for further examination. We found the antibody of intrinsic factor was negative and his gastroscope was normal. Since his grandmother and his father also had mild anemia, cobalamin concentration was then tested, and they were both diagnosed to have vitamin B12 deficiency. (Fig. 1). Therefore, hereditary disease was further suspected, and we performed genome sequencing to convince it.

\section{Analysis of genome sequencing}

Genomic DNA was isolated from the peripheral blood of the patient. SeqCap EZ Choice XL Library (Roche NimbleGen) was used to hybridize the exons and adjacent intron regions ( $50 \mathrm{bp}$ ) of 238 genes related to hereditary hematological diseases. After amplification and purification, high-throughput sequencing was performed by Illumina. Analysis was performed using the hg19 annotation information provided by UCSC. Genomic DNA samples of the patient's parents and grandparents were then isolated for validation of the identified mutations

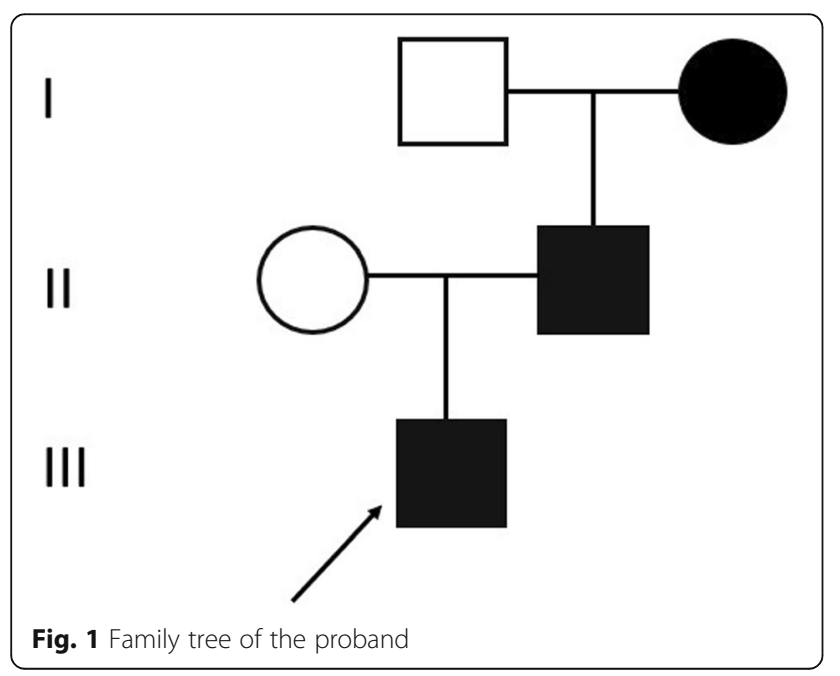

by Sanger sequencing. The patient had compound heterozygous mutation in GIF gene (Fig. 2). There was a c.776delA mutation combined with c.585C $>$ A mutation on the other allele. c.776delA (p.Q259Rfs*17) is a frame shift mutation in exon 6 caused by 1 bp deletion which would result in abnormal protein translation. It was also found in father and grandmother of the proband. c.585C > A (p.Y195X) is a nonsense mutation in exon 5 that would lead to the early termination of the gene coding protein and was also detected in his mother. Since there are reports for mutations of the downstream coding sites that could result in abnormal function of the gastric intrinsic factor, these two mutations are both thought to cause pathological changes.

\section{Discussion and conclusions}

Juvenile cobalamin deficiency usually presents with various hematological problems ranging from mild weakness to liftthreatening anemia. Patients may present with yellow skin caused by combined anemia and jaundice. Rate of infection is also increased due to neutropenia, thrombocytopenia and megaloblastic anemia. The neurologic abnormalities are also variable and may not be recognized without attention. Growth retardation and learning difficulties are more commonly seen in the juveniles [4]. Patients may also have dementia, psychological problems and neurodegeneration of the spinal cord.

Although inborn cobalamin deficiency is rare, with social and economic development, dietary and infectious causes of cobalamin deficiency are decreased and the prevalence of inherited cobalamin deficiency has increased [5]. Inborn errors affecting intestinal cobalamin absorption, transport of cobalamin in blood, uptake of cobalamin by cells or intracellular cobalamin metabolism could all cause cobalamin deficiency. As for hereditary cobalamin malabsorption, IGS caused by CUBN or $A M N$ mutations and IFD caused by GIF mutations are most common ones. Schilling test was used in the past to differentiate IFD from IGS and has been obsoleted because of invasiveness and lack of access to the radiolabeled vitamin B12. Genetic testing is now available for the validation and classification of the inherited cobalamin malabsorption. Tanner et al. 2012 [3] observed 22\%, 42\%, $36 \%$ of the mutations in GIF, CUBN and AMN genes respectively in a large genetic screening study of 154 families or patients with hereditary deficiency of vitamin B12 absorption.

Hereditary intrinsic factor deficiency is characterized by cobalamin deficiency with the lack of gastric intrinsic factor because of GIF mutations. The gastric acid secretion and gastroscopy are often normal and no autoantibodies to intrinsic factor should be found. We summarized the mutations in GIF from previous literature in Table 1. The first report with identified genetic mutations was in 2004 [6]. Yassin et al. [6] identified a 4-base deletion (c183_ 


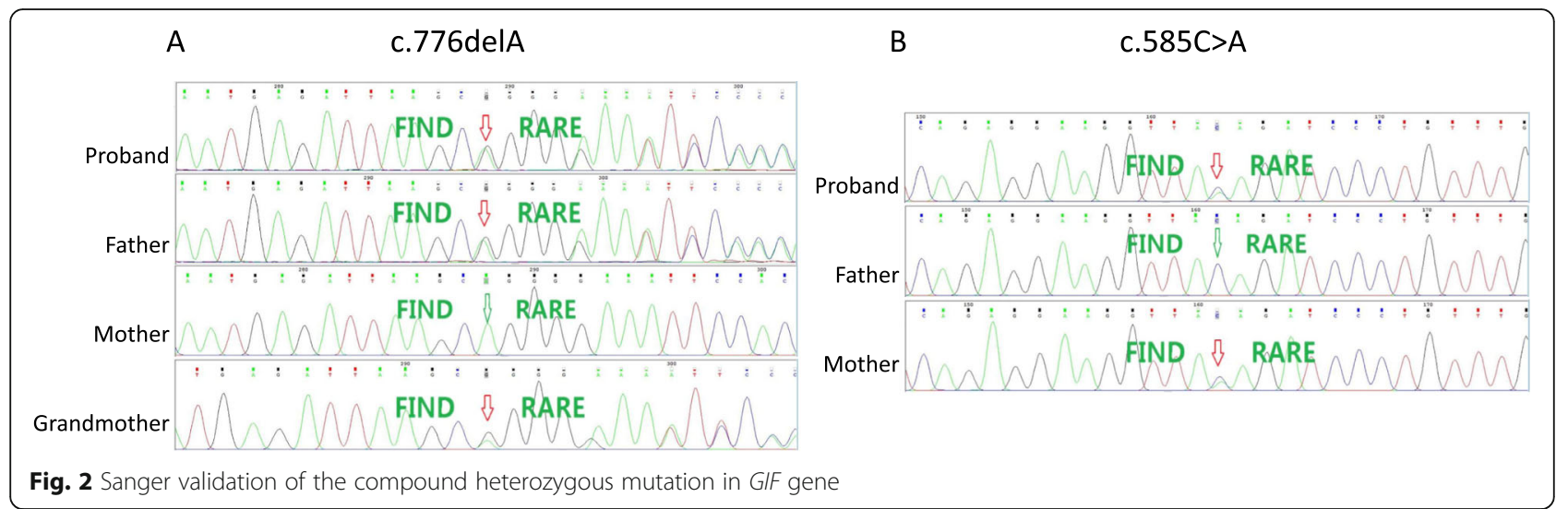

Table1 Summary mutations in the GIF gene according to previous literature (add to page 5 line 19)

\begin{tabular}{|c|c|c|c|c|c|}
\hline DNA mutation & Region & Genotype & Predicted consequence & References & Origin \\
\hline$c .79+1 G>A$ & intron 1 & hom & splice site mutation & $\begin{array}{l}\text { Tanner et al. } 2005 \text { [5], Tanner et al. } \\
2012 \text { [3] }\end{array}$ & $\begin{array}{l}\text { France, Norway, } \\
\text { USA }\end{array}$ \\
\hline $\begin{array}{l}\text { c. } 79+1 G>A \text { A del Intron } 8 \\
\text { to distal of } 3 \text { '-end }\end{array}$ & $\begin{array}{l}\text { intron } 1 \& \\
\text { del }\end{array}$ & comp het & $\begin{array}{l}\text { splice site mutation \& partial } \\
\text { gene deletion }\end{array}$ & Tanner et al. 2012 [3] & Norway \\
\hline$c .79+1 G>A \&$ \& $.137 C>T$ & $\begin{array}{l}\text { intron } 1 \& \\
\text { exon } 2\end{array}$ & comp het & $\begin{array}{l}\text { splice site mutation \& } \\
\text { p.Ser46Leu }\end{array}$ & Tanner et al. 2012 [3] & $\begin{array}{l}\text { USA (Western } \\
\text { Europe?) }\end{array}$ \\
\hline$c .79+1 G>A \&$ c. $290 T>C$ & $\begin{array}{l}\text { intron } 1 \& \\
\text { exon } 3\end{array}$ & comp het & $\begin{array}{l}\text { splice site mutation \& } \\
\text { p.Met97Thr }\end{array}$ & Overgaard et al. 2010 [10] & $\begin{array}{l}\text { USA (Western } \\
\text { Europe?) }\end{array}$ \\
\hline$c .79+1 G>A \&$ c $.673 A>C$ & $\begin{array}{l}\text { intron } 1 \& \\
\text { exon } 5\end{array}$ & comp het & $\begin{array}{l}\text { splice site mutation \& } \\
\text { p.Ser225Arg }\end{array}$ & Tanner et al. 2012 [3] & Siberia \\
\hline c. $80-1 \mathrm{G}>\mathrm{A}$ & intron 1 & hom & splice site mutation & Tanner et al. 2005 [5] & Kuwaiti \\
\hline C. $137 C>T$ & exon 2 & hom & p.Ser46Leu & $\begin{array}{l}\text { Tanner et al. } 2005 \text { [5], Tanner et al. } \\
2012 \text { [3] }\end{array}$ & Turkey \\
\hline c.161delA & exon 2 & hom & p.Asn54fs & Tanner et al. 2005 [5] & Turkey \\
\hline c.183_186delGAAT & exon 2 & hom & p.Met61fs & $\begin{array}{l}\text { Yassin et al. } 2004 \text { [6], Tanner et al. } 2005 \\
\text { [5], Ament et al. } 2009 \text { [8] }\end{array}$ & $\begin{array}{l}\text { UK (Jamaican), } \\
\text { African American }\end{array}$ \\
\hline $\begin{array}{l}\text { c.183_186delGAAT \& } \\
\text { c.659T > C }\end{array}$ & $\begin{array}{l}\text { exon } 2 \& \\
\text { exon } 5\end{array}$ & comp het & p.Met61fs \& p.lle220Thr & Ament et al. 2009 [8] & $\begin{array}{l}\text { USA (African, } \\
\text { European) }\end{array}$ \\
\hline c. $256+2 T>G$ \& c.659 T>C & $\begin{array}{l}\text { intron } 2 \& \\
\text { exon } 5\end{array}$ & comp het & $\begin{array}{l}\text { splice site mutation \& } \\
\text { p.lle220Thr }\end{array}$ & García Jiménez et al. 2008 [12] & Spain \\
\hline c. $290 \mathrm{~T}>\mathrm{C} \&$ ? & exon $3 \&$ ? & comp het & p.Met97Thr \& ? & Tanner et al. 2012 [3] & Finland \\
\hline $\begin{array}{l}\text { GIF c.290 T > C \& FUT2 } \\
\text { rs601338 461GG variant }\end{array}$ & & comp het & $\begin{array}{l}\text { GIF p.Met97Thr \& FUT2 } \\
\text { secretor variant }\end{array}$ & Chery et al. 2013 [13] & France \\
\hline $\begin{array}{l}\text { c.431_438delAGAAGAAC \& } \\
\text { c.974_975insG }\end{array}$ & $\begin{array}{l}\text { exon } 4 \& \\
\text { exon7 }\end{array}$ & comp het & p.Gln144fs \& p.Val325fs & Tanner et al. 2012 [3] & Austria \\
\hline $\begin{array}{l}\text { c.435_437delGAA \& FUT2 } \\
\text { rs601338 461GG variant }\end{array}$ & & comp het & $\begin{array}{l}\text { p.Lys145_Asn146delinsAsn \& } \\
\text { FUT2 secretor variant }\end{array}$ & Chery et al. 2013 [13] & France \\
\hline C.469 T > C \& ? & exon $4 \&$ ? & comp het & p.Phe157Leu \& ? & Tanner et al. 2012 [3] & USA (Lebanese) \\
\hline c. $685 \mathrm{G}>\mathrm{A}$ & exon 5 & hom & p.Ala229Thr & Tanner et al. 2012 [3] & $\begin{array}{l}\text { Turkey, Germany } \\
\text { (Lebanese) }\end{array}$ \\
\hline c. $938 \mathrm{C}>\mathrm{T} \&$ ? & exon $7 \&$ ? & comp het & p.Thr313lle \& ? & Tanner et al. 2012 [3] & Israel (Arabic) \\
\hline c. $1073+5 G>A$ & intron 7 & hom & splice site mutation & Sturm et al. 2013 [11] & USA (Chaldean) \\
\hline c.1175_1176insT & exon 8 & hom & p.Thr393fs & Tanner et al. 2005 [5] & Turkey \\
\hline c. $1222 \mathrm{G}>\mathrm{A}$ & exon 9 & hom & p.Glu408Lys & Lund Leunbach et al. 2011 & Danish \\
\hline
\end{tabular}


186delGAAT, p.Met61fs) in exon 2 in an 11-year-old girl with severe anemia and cobalamin deficiency. This homozygous mutation seems to originate in Africa and was also reported by Tanner et al. 2005 [7] and Ament et al. 2009 [8]. In Exon 2, another 2 homozygous mutation sites were also found including the c.137C $>\mathrm{T}$ (p.Ser46Leu) and c.161delA (p.Asn54fs). There are also homozygous mutations in exon 5 (c.685G > A) [3], exon 8 (c.1175_1176insT) [7] and exon 9 (c.1222G > A) [9]. Intron mutations in the splice site can also cause abnormal protein structures and functions. The most numerous one was c.79+1G > A mutation commonly found in Europe. Not only the homozygous mutation of this site but also in combination with other defects including a 3-terminal deletion in intron 8 and 3 different missense mutation sites (c.137C $>\mathrm{T}$, c.290 T > C [10], c.673A > C). c.80-1G > A in intron 1 [7] and c.1073 + 5G > A [11] homozygous mutations were reported respectively in West Asia area. There are also compound heterozygous mutations in two exons that generate IFD $[8,12]$. Notably, Chery et al. [13] reported 2 IFD family who carried FUT2 rs601338 secretor variants that impairs GIF secretion. This variant in combination with GIF heterozygous mutation worsened the B12 status.

As for this patient, we found a c.776delA frame shift mutation in exon 6 combined with c. $585 \mathrm{C}>\mathrm{A}$ nonsense early termination mutation in exon 5 and the two mutation alleles were inherited from his parents respectively. This compound heterozygous mutation caused the severe loss of function of the encoding gastric intrinsic factor protein and resulted in cobalamin deficiency. It was the first identified novel mutation of GIF in East-Asia and may indicate a new ancestry.

The treatment is merely vitamin B12 administration by several routes including intramuscular and oral. Our patient recovered the hemoglobin level each time after applying vitamin B12. In fact, treatment with life-long cobalamin administration at regular intervals is lifesaving and prevents further deterioration [14]. Early diagnosis and detection by genetic methods in such juvenile cases followed by regular treatment may help avoid severe hematological, neurological and developmental problems.

In summary, we identified a case diagnosed to be hereditary intrinsic factor deficiency firstly with genetic information in the East Asia. A novel compound heterozygous mutation of GIF was reported which may indicate a different origin from previous literature.

\section{Abbreviations}

GIF: Gastric intrinsic factor; IGS: Imerslund-Grasbeck syndrome; IFD: Intrinsic factor deficiency

\section{Acknowledgements}

We thank the proband and his family. Their cooperation and helpful comments contributed to this discovery.

\section{Authors' contributions}

$\mathrm{BH}$ designed the research study. JR analyzed the data and was a major contributor in writing the manuscript. MC and JZ made the follow-up of the patient and analyzed the clinical information. FC, YH and WZ collected the medical record and analyzed the sequencing data. All authors revised and approved the final manuscript.

\section{Funding}

This study was supported by grants from the Chinese Academy of Medical Sciences innovation fund for medical sciences (2016-12M-3-004), mainly used in genome sequencing.

\section{Availability of data and materials}

The datasets generated and/or analyzed during the current study are available in the NCBI BioProject database under the accession number PRJNA669950. The hg19 annotation dataset could be reached at https:// genome.ucsc.edu/.

\section{Ethics approval and consent to participate}

Written informed consent was obtained from the proband and his family and the study was conducted in accordance with the Declaration of Helsinki. The study protocol was approved by the Ethics Committee of Peking Union Medical College Hospital.

\section{Consent for publication}

Written Consent for publication of the patient's, the parents' and the grandparents' clinical details and/or clinical images was obtained from the parents of the proband and the grandparents of the patient.

\section{Competing interests}

The authors declare that they have no conflict of interest.

Received: 22 July 2019 Accepted: 27 October 2020

Published online: 10 November 2020

\section{References}

1. Hunt A, Harrington D, Robinson S. Vitamin B12 deficiency. BMJ. 2014;349: g5226.

2. Grasbeck R. Imerslund-Grasbeck syndrome (selective vitamin B(12) malabsorption with proteinuria). Orphanet J Rare Dis. 2006;1:17.

3. Tanner SM, Sturm AC, Baack EC, Liyanarachchi S, de la Chapelle A. Inherited cobalaminmalabsorption. Mutations in three genes reveal functional and ethnic patterns. Orphanet J Rare Dis. 2012;7(1):56.

4. Grasbeck R, Tanner SM. Juvenile selective vitamin B(1)(2) malabsorption: 50 years after its description-10 years of genetic testing. Pediatr Res. 2011;70(3): 222-8.

5. Watkins D, Rosenblatt DS. Inborn errors of cobalamin absorption and metabolism. Am J Med Genet C Semin Med Genetics. 2011;157c(1):33-44.

6. Yassin F, Rothenberg SP, Rao S, Gordon MM, Alpers DH, Quadros EV. Identification of a 4-base deletion in the gene in inherited intrinsic factor deficiency. Blood. 2004;103(4):1515-7.

7. Tanner SM, Li Z, Perko JD, Oner C, Cetin M, Altay C, Yurtsever Z, David KL, Faivre L, Ismail EA, et al. Hereditary juvenile cobalamin deficiency caused by mutations in the intrinsic factor gene. ProcNatIAcadSci USA. 2005;102(11): 4130-3.

8. Ament AE, Li Z, Sturm AC, Perko JD, Lawson S, Masterson M, Quadros EV, Tanner SM. Juvenile cobalamin deficiency in individuals of African ancestry is caused by a founder mutation in the intrinsic factor gene GIF. Br J Haematol. 2009;144(4):622-4.

9. Leunbach TL, Johansen P, Tanner SM, Grasbeck R, Helgestad J. Homozygous mutation in the intrinsic factor gene in a child with severe vitamin B12 deficiency. UgeskrLaeger. 2011;173(34):2047-8. .

10. Overgaard UM, Tanner SM, Birgens HS. Vitamin B12 deficiency in a 15-year old boy due to mutations in the intrinsic factor gene GIF. Br J Haematol. 2010;150(3):369-71.

11. Sturm AC, Baack EC, Armstrong MB, Schiff D, Zia A, Savasan S, de la Chapelle A, Tanner SM. Hereditary intrinsic factor deficiency in chaldeans. JIMD Rep. 2013;7:13-8. .

12. Garcia Jimenez MC, Baldellou Vazquez A, Calvo Martin MT, Perez-Lungmus $\mathrm{G}$, Lopez Pison J. Hereditary juvenile cobalamin deficiency due to mutations in GIF gene. An PediatrBarc. 2008;69(1):56-8. . 
13. Chery C, Hehn A, Mrabet N, Oussalah A, Jeannesson E, Besseau C, Alberto JM, Gross I, Josse T, Gerard P, et al. Gastric intrinsic factor deficiency with combined GIF heterozygous mutations and FUT2 secretor variant. Biochimie. 2013:95(5):995-1001. .

14. BoinaAbdallah A, Ogier de Baulny H, Kozyraki R, Passemard S, Fenneteau O, Lebon S, Rigal O, Mesples B, Yacouben K, Giraudier S, et al. How can cobalamin injections be spaced in long-term therapy for inborn errors of vitamin B(12) absorption? Mol Genet Metab. 2012;107(12):66-71.

\section{Publisher's Note}

Springer Nature remains neutral with regard to jurisdictional claims in published maps and institutional affiliations.

Ready to submit your research? Choose BMC and benefit from:

- fast, convenient online submission

- thorough peer review by experienced researchers in your field

- rapid publication on acceptance

- support for research data, including large and complex data types

- gold Open Access which fosters wider collaboration and increased citations

- maximum visibility for your research: over $100 \mathrm{M}$ website views per year

At $\mathrm{BMC}$, research is always in progress.

Learn more biomedcentral.com/submissions 